66 (2): 2021

267-276

\title{
PHYSICAL AND MECHANICAL CHARACTERIZATION OF PLANCHONELLA PACHYCARPA WOOD SPECIES FOR USE IN STRUCTURAL PURPOSE
}

\author{
Vinicius Borges De Moura Aquino, Marcus Vinicius Pereira De Freitas, \\ Claudia Queiroz De Vasconcelos \\ Federal University Of Southern And Southeastern Pará \\ BRAZIL \\ João Paulo Boff Almeida, Felipe Nascimento Arroyo, \\ Edson Fernando Castanheira Rodrigues, André Luis Christoforo \\ Federal University Of São Carlos \\ BRAZIL
}

Diego Henrique De Almeida

Federal University Of Rondonia BRAZIL

Sergio Augusto Mello Silva

São Paulo State University

BRAZIL

Diogo Aparecido Lopes Silva Federal University Of São Carlos BRAZIL

Roberto Vasconcelos Pinheiro Mato Grosso State University BRAZIL

Francisco Antonio Rocco Lahr

University Of São Paulo BRAZIL

(Received April 2020) 


\begin{abstract}
This research aimed to characterize the wood species Goiabão (Planchonella pachycarpa), following the precepts set forth in the Brazilian standard ABNT NBR 7190, as well as to evaluate the possibility of estimating physical and mechanical properties, using the analysis of variance (ANOVA) as a function of apparent density, and also to estimate the stiffness properties as a function of the respective strength property. The physical and mechanical properties were considered adequate for the use of this wood for structural purposes, being classified in class $\mathrm{C} 40$. According to the results of the regression models, it is possible to estimate the tensile strength parallel to the fibers as a function of the apparent density. It was also possible to estimate the longitudinal elastic modulus in the compression parallel to the fibers as a function of the compressive strength parallel to the fibers.
\end{abstract}

KEYWORDS: Planchonella pachycarpa, apparent density, regression models, analysis of variance (ANOVA).

\title{
INTRODUCTION
}

Considering that wood is a natural material, subject to different edaphoclimatic conditions (Lahr et al. 2016c, Silva et al. 2018, Morando et al. 2019) and that Brazil is the country with the largest number of tree species (Beech et al. 2017, Steege et al. 2016, ter Steege et al. 2019). The characterization of new species of wood must also be carried out so that there is no predatory use of known species, which can lead them to extinction (Cardoso et al. 2012, Couto et al. 2018, Nogueira et al. 2019). Thus, the species Planchonella pachycarpa can be an alternative for use with structural purposes. This species is present in the Brazilian states of Pará, Mato Grosso, Amazonas (Lorenzi 1998).

In Brazil, the characterization of wood species for structural use, as well as the requirements for dimensioning and classification of wood are recommended by the Brazilian standard ABNT NBR 7190 (ABNT 1997), on specimens with no defects. The characterization tests are analogous to those recommended in the international standard ISO 13061 (2017). An alternative to estimate physical and mechanical properties in a simple and effective way with the use of mathematical methods is to use the apparent density, defined as the ratio between mass and apparent volume at $12 \%$ moisture content, a property of easy experimental determination (Christoforo et al. 2017, Couto et al. 2018, Dias and Lahr 2004, Lahr et al. 2016c, Lobão et al. 2004).

In the design of wooden structures, such as bridges, roofs, walkways and residences, rigidity properties are used, as well as strength properties. How obtaining those properties requires a higher level of complexity in the equipment compared to obtaining the strength properties (Dadzie and Amoah 2015, Komariah et al. 2015, Logsdon et al. 2005, Machado et al. 2014, Ruelle et al. 2011), it is important to evaluate the possibility of estimating the stiffness properties as a function of the respective strength property.

Thus, this work aimed to present the physical and mechanical characterization of the wood species Planchonella pachycarpa, a wood species in which there are no studies in the literature. In addition to characterizing, this study aimed to evaluate the possibility of estimating physical and mechanical properties as a function of apparent density, rigidity properties as a function of the respective strength property, as well as evaluating the relationships between the strength properties and comparing with the arranged relationships in the Brazilian standard ABNT NBR 7190 (ABNT 1997). 


\section{MATERIAL AND METHODS}

The samples of Planchonella pachycarpa wood were properly stored, which resulted in equilibrium moisture content close to 12\% according to ABNT NBR 7190 (1997). The tests were performed at the Laboratory of Wood and Wood Structures (LaMEM), Department of Structural Engineering (SET), São Carlos School of Engineering (EESC), University of São Paulo (USP). The physical and mechanical properties were obtained in accordance with the requirements of the Brazilian standard ABNT NBR 7190 (1997), set out in its Annex B, determining the following physical and mechanical properties: apparent density $\left(\rho_{\text {ap, } 12 \%}\right)$, total radial shrinkage (TRR), total tangential shrinkage (TTR), compressive strength parallel to the grain $\left(f_{c 0}\right)$, tensile strength parallel to fibers $\left(f_{t 0}\right)$, tensile strength normal to thegrain $\left(f_{t 90}\right)$, shearstrength parallel to thegrain $\left(f_{v 0}\right)$, splittingstrength $\left(f_{s 0}\right)$, conventionalstrength on static bending test $\left(f_{m}\right)$, modulus of elasticity in parallel directions to the grain $\left(\mathrm{E}_{\mathrm{c} 0}\right)$, modulus of elasticity in tension parallel to the grain $\left(\mathrm{E}_{\mathrm{t} 0}\right)$, conventional modulus of elasticity on static bending test $\left(\mathrm{E}_{\mathrm{m}}\right)$, hardness parallel to the grain $\left(\mathrm{f}_{\mathrm{H} 0}\right)$, hardness normal to the grain $\left(\mathrm{f}_{\mathrm{H} 90}\right)$ and toughness (W). On Fig. 1, it is described the dimensions of wood specimens.
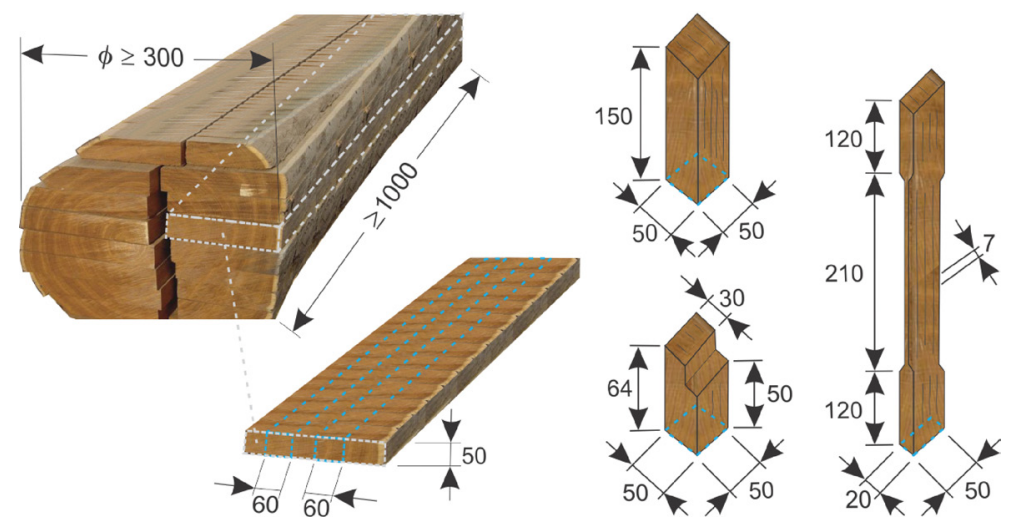

Fig. 1: Dimension of wood specimens and description of their extraction on timber (Dimension in mm). Source: Morando et al. (2019).

It should be noted that 15 values for each one of its physical (3) and mechanical properties (12) were investigated, resulting in 225 experimental values obtained. Planchonella pachycarpa wood was classified in the appropriate strength class (ABNT 1997) according to the characteristic value of the compressive strength parallel to the fibers $\left(\mathrm{f}_{\mathrm{c} 0, \mathrm{k}}\right)$.

The classification of Peltophorum vogelianum wood in the strength classes for wood of the dicotyledon group was made using Eq. 1 , where $f_{k}$ is the characteristic strength value and $n$ is the number of test pieces used. It should be noted from Eq. 1 that the results of strength should be placed in ascending order $f_{1} \leq f_{2} \leq \ldots \leq f_{n}$, ignoring the highest value if the number of specimens is odd, and not taking $f_{k}$ below $f_{1}$ nor 0.70 of the average value:

$$
f_{c 0, k}=\left(2 \cdot \frac{f_{1}+f_{2}+f_{3}+\ldots+f_{(n / 2)-1}}{(n / 2)-1}-f_{n / 2}\right) \cdot 1.10
$$


Regression models (Eqs. 2-5) based on analysis of variance (ANOVA) were used to estimate the strength and stiffness properties as a function of the apparent density of the wood and also the stiffness as a function of strength, with $Y$ being the estimated property (variable dependent), $X$ the independent variable and $\mathrm{b}$ and the parameters adjusted by the Least squares method:

$$
\begin{aligned}
& Y=a+b \cdot X \quad[\text { Lin - linear }] \\
& Y=a \cdot e^{b \cdot X} \quad[\text { Exp - exponential }] \\
& Y=a+b \cdot \operatorname{Ln}(X) \quad[\text { Log - logarithmic }] \\
& Y=a \cdot X^{b} \quad[\text { Geo - geometric }]
\end{aligned}
$$

By the ANOVA of the regression models, it is considered at the level of $5 \%$ of significance $(\alpha)$, the null hypothesis formulated consisted of the non-representativeness of the tested models $\left(H_{0}: \beta=0\right)$ and in the representativeness as an alternative hypothesis. P-value higher than the significance level implies the acceptance of $H_{O}$ (the model is not representative - the variations of the independent variable are not able to explain the variations in the estimated properties), refuting it otherwise (the tested model is representative). The determination coefficient $\left(R^{2}\right)$ was used to assess the quality of the adjustments obtained, making it possible to choose the best precision for each evaluated relationship. It should be noted that 56 regression models were used for density as an estimator of the fourteen other variables (including physical properties TRR and TTR), and 16 other models for strength properties as estimators of stiffness, which resulted in 72 equations in all.

\section{RESULTS AND DISCUSSION}

Tab. 1 presents the average values $\left(X_{m}\right)$, coefficients of variation $\left(C_{\eta}\right)$, maximum values (Max) and minimum values (Min), the confidence interval of the mean (CI - 95\% reliability) of the physical and mechanical properties of the wood. of Goiabão wood species, as well as the characteristic values of the mechanical properties.

Tab. 1: Descriptive statistics of experimentally obtained values for wood species Planchonella pachycarpa.

\begin{tabular}{|l|c|c|c|c|c|c|}
\hline \multicolumn{1}{|c|}{ Property } & $\mathbf{X}_{\mathbf{m}}$ & Min & Max & $\mathbf{C V ~ ( \% )}$ & $\mathbf{C I}$ & $\mathbf{f}_{\mathbf{w k}}$ \\
\hline$\rho_{\mathrm{ap}, 12 \%}\left(\mathrm{~g} \cdot \mathrm{cm}^{-3}\right)$ & 0.93 & 7.00 & 0.80 & 7.00 & $0.88 ; 0.97$ & - \\
\hline TRR $(\%)$ & 8.90 & 15.00 & 6.90 & 15.00 & $8.08 ; 9.71$ & - \\
\hline $\mathrm{TTR}(\%)$ & 18.84 & 9.00 & 15.60 & 9.00 & $17.81 ; 19.86$ & - \\
\hline $\mathrm{f}_{\mathrm{c} 0}(\mathrm{MPa})$ & 48.40 & 12.00 & 41.00 & 12.00 & $44.58 ; 52.21$ & 43.10 \\
\hline $\mathrm{f}_{\mathrm{t} 0}(\mathrm{MPa})$ & 119.33 & 30.00 & 66.00 & 30.00 & $97.10 ; 141.57$ & 70.13 \\
\hline $\mathrm{f}_{\mathrm{t} 90}(\mathrm{MPa})$ & 8.70 & 22.00 & 5.20 & 22.00 & $7.49 ; 9.91$ & 5.79 \\
\hline $\mathrm{f}_{\mathrm{v} 0}(\mathrm{MPa})$ & 14.00 & 15.00 & 11.00 & 15.00 & $12.72 ; 15.27$ & 12.14 \\
\hline $\mathrm{f}_{\mathrm{s} 0}(\mathrm{MPa})$ & 1.16 & 26.00 & 0.90 & 26.00 & $0.97 ; 1.35$ & 1.01 \\
\hline $\mathrm{f}_{\mathrm{M}}(\mathrm{MPa})$ & 106.50 & 12.00 & 84.00 & 12.00 & $99.14 ; 113.85$ & 91.12 \\
\hline $\mathrm{E}_{\mathrm{c} 0}(\mathrm{MPa})$ & 18716 & 15.00 & 13501 & 15.00 & $16982 ; 20449$ & - \\
\hline $\mathrm{E}_{\mathrm{t} 0}(\mathrm{MPa})$ & 18267 & 17.00 & 11468 & 17.00 & $16294 ; 20240$ & - \\
\hline
\end{tabular}


Vol. $66(2): 2021$

\begin{tabular}{|l|c|c|c|c|c|c|}
\hline $\mathrm{E}_{\mathrm{M}}(\mathrm{MPa})$ & 18367 & 16.00 & 14361 & 16.00 & $16488 ; 20245$ & - \\
\hline $\mathrm{f}_{\mathrm{H} 0}(\mathrm{MPa})$ & 109.67 & 6.00 & 93.00 & 6.00 & $105.86 ; 113.48$ & 114.56 \\
\hline $\mathrm{f}_{\mathrm{H} 90}(\mathrm{MPa})$ & 100.00 & 8.00 & 81.00 & 8.00 & $94.91 ; 105.09$ & 104.04 \\
\hline $\mathrm{W}(\mathrm{N} \cdot \mathrm{m})$ & 21.09 & 20.00 & 12.90 & 20.00 & $18.48 ; 23.69$ & - \\
\hline
\end{tabular}

Considering the characteristic value of the compressive strength parallel to the $f_{c 0, k}$ (43 MPa) fibers of Planchonella pachycarpa wood, this wood is classified as $\mathrm{C} 40$ of dicotyledons, the same class of wood species Erisma uncinatum (Almeida et al. 2019), Vataireopsis araroba (Almeida et al. 2016), Vatairea sp. (Lahr et al. 2016a), Mimosa caesalpiniaefolia (Nascimento et al. 2018) and Copaifera sp. (Aquino et al. 2018a), wood species used for structural purposes (ABNT 1997). Considering the data in the literature, the value of compressive strength parallel to Goiabão fibers is close to that found by Dias and Lahr (49 MPa) (Dias and Lahr 2004), a value close to that found in the present work. The Goiabão wood species can be considered very heavy $\left(\rho_{\mathrm{ap}, 12 \%}=0.92 \mathrm{~g} \cdot \mathrm{cm}^{-3}\right)$ (Dias and Lahr 2004), with density similar to the species Manilkara buberi and Mezilaurus itauba (Silveira et al. 2013).

Evaluating the values of the coefficients of variation, the Brazilian standard ABNT NBR 7190 (ABNT 1997) establishes that the maximum value of the coefficient of variation for the characterization if considered adequate, that is, to have statistical significance without further analysis, must be $18 \%$ for normal efforts and $28 \%$ for tangential efforts. The tensile strength parallel to the grain $\left(f_{t 0}\right)$ property presented a value above that allowed by norm. This may occur due to the inherent variability in the tensile strength test parallel to the fibers (Christoforo et al. 2020, Pertuzzatti et al. 2018), as well as the shape of the rupture, in which it is fragile, as well as the rupture plane in the tested specimen, which can be explained by internal anatomical structure, which demands more studies on such a rupture (Morando et al. 2019). Tab. 2 presents the best adjustments obtained using regression models for the apparent density in the estimation of the other properties, underlining the models considered significant by ANOVA (5\% significance).

Tab. 2: Regression models based on apparent density as an estimator of the other properties.

\begin{tabular}{|l|l|c|c|c|c|}
\hline Property & Regression model (ANOVA) & P-value & $\mathbf{a}$ & $\mathbf{b}$ & $\mathbf{R}^{\mathbf{2}}(\mathbf{\%})$ \\
\hline $\mathrm{TRR}$ & Logarithmic & 0.4200 & 8.61 & -4.35 & 6.60 \\
\hline $\mathrm{TTR}$ & Linear & 0.7518 & 21.03 & -2.34 & 1.05 \\
\hline $\mathrm{f}_{\mathrm{c} 0}$ & Exponential & 0.2584 & 26.80 & 0.62 & 12.55 \\
\hline $\mathrm{f}_{\mathrm{t} 0}$ & Exponential & $\underline{0.0001}$ & 2.83 & 3.93 & 81.21 \\
\hline $\mathrm{f}_{\mathrm{t} 90}$ & Logarithmic & 0.3558 & 9.18 & 7.20 & 8.57 \\
\hline $\mathrm{f}_{\mathrm{v} 0}$ & Geometric & 0.3696 & 13.31 & -0.59 & 8.11 \\
\hline $\mathrm{f}_{\mathrm{s} 0}$ & Linear & 0.2681 & -0.24 & 1.49 & 12.09 \\
\hline $\mathrm{f}_{\mathrm{M}}$ & Geometric & 0.2604 & 109.91 & 0.58 & 12.46 \\
\hline $\mathrm{f}_{\mathrm{H} 0}$ & Linear & 0.8716 & 105.29 & 4.65 & 0.27 \\
\hline $\mathrm{f}_{\mathrm{H} 90}$ & Geometric & 0.6216 & 98.50 & -0.18 & 2.53 \\
\hline $\mathrm{W}$ & Exponential & 0.3653 & 46.49 & -0.86 & 8.25 \\
\hline $\mathrm{E}_{\mathrm{c} 0}$ & Geometric & 0.2345 & 19459.84 & 0.74 & 13.80 \\
\hline $\mathrm{E}_{\mathrm{t} 0}$ & Geometric & $\underline{0.0136}$ & 20118.27 & 1.68 & 47.14 \\
\hline $\mathrm{E}_{\mathrm{M}}$ & Geometric & 0.0801 & 19453.19 & 1.02 & 27.48 \\
\hline
\end{tabular}

The apparent density was considered significant only in the estimate of the tensile strength 
parallel to the fibers $\left(f_{t 0}\right)\left(\mathrm{R}^{2}=81.21 \%\right)$ and longitudinal elastic modulus in the tensile parallel to the fibers $\left(E_{t 0}\right)\left(\mathrm{R}^{2}=47.14 \%\right)$, with the exponential and geometric models of best fit for these properties, respectively. Fig. 2 illustrates the two regression models considered significant.

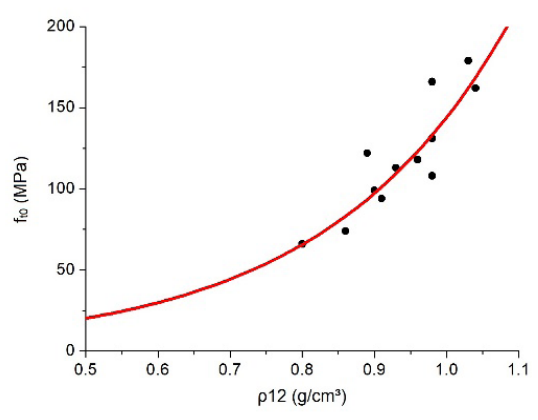

(a)

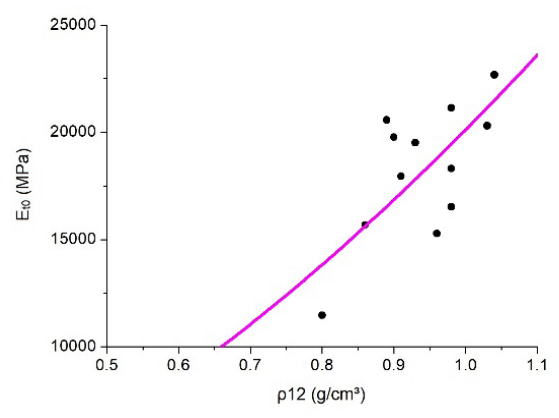

(b)

Fig. 2: Graph of the density models as an estimation of the tensile strength (a) and of the longitudinal elastic modulus in the tension (b).

Observing the adjustments considered significant shown in Tab. 3, it can be considered that it is possible to use the apparent density as an estimator of the tensile strength parallel to the fibers due to the high value of the coefficient of determination, with good quality in the adjustment $\left(R^{2}>70 \%\right)$. However, for the tensile modulus it is not possible due to the poor quality of the fit. In several works in the literature it was not possible to find significant relationships between physical and mechanical density and property (Aquino et al. 2018b, Christoforo et al. 2019, Lahr et al. 2016b, Montgomery 2012, Morando et al. 2019, Nogueira et al. 2019).

Tab. 3 illustrates the best adjustments obtained in the estimation of the stiffness properties as a function of the respective strength property.

Tab. 3: Regression models for estimating stiffness properties as a function of strength properties.

\begin{tabular}{|l|l|c|c|c|c|c|}
\hline Property & Regression model (ANOVA) & P-value & $\mathrm{a}$ & $\mathrm{b}$ & Expression & $\mathrm{R}^{2}(\%)$ \\
\hline $\mathrm{E}_{\mathrm{c} 0}$ & Logarithmic & $\underline{0.0001}$ & -57362 & 19644 & $E_{c 0}=a+b \cdot \ln \left(f_{c 0}\right)$ & 79.13 \\
\hline $\mathrm{E}_{\mathrm{t} 0}$ & Geometric & $\underline{0.0179}$ & 2638 & 0.40 & $E_{t 0}=a \cdot f_{t 0}{ }^{b}$ & 44.41 \\
\hline $\mathrm{E}_{\mathrm{M}}$ & Logarithmic & 0.6964 & 4600 & 2954 & $E_{M}=a+b \cdot \ln \left(f_{m}\right)$ & 1.59 \\
\hline
\end{tabular}

Considering the data in Tab. 3, it appears that the models using the modules of longitudinal elasticity to parallel compression and parallel traction were significant. Based on the quality of the fit, the resistance to parallel compression can be used to estimate the elasticity module to compression parallel to the fibers $\left(\mathrm{R}^{2}>70 \%\right)$. As for the longitudinal elastic modulus in traction, this is not possible due to the poor quality of the fit. In the literature, Guarucaia wood specie did not present significant models for estimating the rigidity property as a function of the respective strength (Christoforo et al. 2019). Fig. 3 shows the models considered significant. 


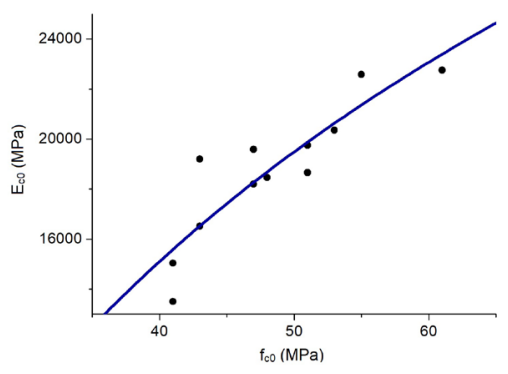

(a)

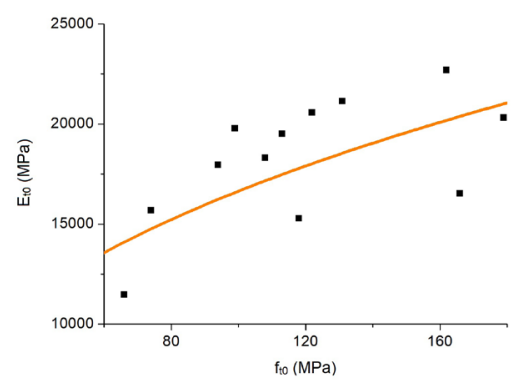

(b)

Fig. 3: Graph of the strength (compression and tension parallel to the grain) models as an estimation of the longitudinal elastic modulus on compression (a) and of the longitudinal elastic modulus in the tension (b).

\section{CONCLUSIONS}

Based on the results presented in the present research, it is concluded that the characterization of the species Planchonella pachycarpa was adequate, following the precepts presented in the Brazilian standard ABNT NBR 7190. The Goiabão species was classified in class $\mathrm{C} 40$ of the hardwoods, based on the characteristic value of the compressive strength parallel to the fibers (ABNT 1997). This classification indicates the possibility of using Goiabão wood species for structural purposes. Evaluating the significant regression models, the apparent density can be used to estimate the tensile strength parallel to the fibers as well as to estimate the longitudinal elasticity module to the compression parallel to the fibers as a function of the compressive strength parallel to the fibers. The models showed good quality in the fit, which shows the possibility of use.

\section{ACKNOWLEDGMENT}

For all the support provided during the production of this research, the authors thank the Coordination for the Improvement of Higher Education (CAPES) and the National Council for Scientific and Technological Development (CNPq).

\section{REFERENCES}

1. ABNT, 1997: Projeto de estruturas de madeira ABNT- Técnicas NBR 7190 (Timber structures design).

2. Almeida, A.S., Criscuolo, G., Almeida, T.H., Christoforo, A.L., Chahud, E., Branco, L.A. M.N., Pinheiro, R.V., Lahr, F.A.R., 2019: Influence of CCA-A Preservative on physicalmechanical properties of Brazilian tropical woods. BioResources 14(2): 3030-3041.

3. Almeida, T.H. De, Almeida, D.H., Christoforo, A.L., Chahud, E., Branco, L.A.M.N., Lahr, F.A.R., 2016: Density as estimator of strength in compression parallel to the grain in wood. International Journal of Materials Engineering 6(3): 67-71. 
4. Aquino, V.B. de M., Almeida, J.P.B., Almeida, D.H., Almeida, T.H., Panzera, T.H., Christoforo, A.L., Lahr, F.A.R., 2018a: Physical and mechanical characterization of Copaifera sp. wood specie. International Journal of Materials Engineering 8(3): 55-58.

5. Aquino, V.B. de M., Panzera, T.H., Magalhães, L.N., Christoforo, A.L., Lahr, F.A.R., 2018b: Physical and mechanical characterization of Ocotea sp. wood specie. Construindo 10(2): 31-40.

6. Beech, E., Rivers, M., Oldfield, S., Smith, P.P., 2017: Global tree search: The first complete global database of tree species and country distributions. Journal of Sustainable Forestry 36(5): 454-489.

7. Cardoso, C.C., Moutinho, V.H.P., Melo, L. de O., Sousa, L.K.V. dos S., de Souza, M.R., 2012: Caracterização físico-mecânica de madeiras amazônicas com aptidão tecnológica para comercialização (Physical-mechanical characterization of Amazonic woods with technological fitness for commercialization). Revista de Ciências Agrárias 55(3): 176-183.

8. Christoforo, A.L., Aftimus, B.H.C., Panzera, T.H., Machado, G. de O., Lahr, F.A.R., 2017: Physico-mechanical characterization of the Anadenanthera colubrina wood specie. Engenharia Agricola 37(2): 376-384.

9. Christoforo, A.L., Aquino, V.B.D.M., Wolenski, A.R.V, Araujo, V.A., Lahr, F.A.R., 2019: Evaluation of the Peltophorum vogelianum Benth. wood species for structural use. Engenharia Agrícola 39(6): 763-768.

10. Christoforo, A.L., Couto, N.G., Almeida, J.P.B., Aquino, V.B.M., Lahr, F.A.R., 2020: Apparent density as an estimator of wood properties obtained in tests where failure is fragile. Engenharia Agrícola 40(1): 105-112.

11. Couto, N.G., Aquino, V.B. de M., Almeida, J.P.B., Almeida, D.H. de, Christoforo, A.L., Lahr, F.A.R., 2018: Determination of physical and mechanical properties of wood specie Dinizia excelsa Ducke. International Journal of Materials Engineering 8(6): 158-161.

12. Dadzie, P.K., Amoah, M., 2015: Density, some anatomical properties and natural durability of stem and branch wood of two tropical hardwood species for ground applications. European Journal of Wood and Wood Products 73(6): 759-773.

13. Dias, F.M., Lahr, F.A.R., 2004: Estimativa de propriedades de resistência e rigidez da madeira através da densidade aparente (Estimation of strength and stiffness properties of wood through apparent density). Scientia Forestalis (65): 102-113.

14. ISO 13061, 2017: Physical and mechanical properties of wood. Test methods for small clear wood specimens.

15. Komariah, R.N., Hadi, Y.S., Massijaya, M.Y., Suryana, J., 2015: Physical-mechanical properties of glued laminated timber made from tropical small-diameter logs grown in Indonesia. Journal of the Korean Wood Science and Technology 43(2): 156-167.

16. Lahr, F.A.R., Aftimus, B.H.C., Arroyo, F.N., Almeida, D.H., Christoforo, A.L., Chahud, E., Branco, L.A.M.N., 2016a: Full characterization of Vatairea sp. wood specie. International Journal of Materials Engineering 6(3): 92-96.

17. Lahr, F.A.R., Arroyo, F.N., Almeida, T.H., Almeida Filho, F.M., Mendes, I.S., Christoforo, A.L., 2016b: Full characterization of Erisma uncinatum Warm wood specie. International Journal of Materials Engineering 6(5): 147-150.

18. Lahr, F.A.R., Christoforo, A.L., da Silva, C.E.G., Andrade, J.R., Pinheiro, R.V., 2016c: Evaluation of physical and mechanical properties of Jatobá (Hymenaea stilbocarpa Hayne) wood with different levels of moisture content and different regions of extracions. Revista Arvore 40(1): 147-154. 
19. Lobão, M.S., Lúcia, R.M. Della, Moreira, M.S.S., Gomes, A., 2004: Caracterização das propriedades fisico-mecânicas da madeira de eucalipto com diferentes densidades (Characterization of the physico-mechanical properties of eucalyptus wood with different densities). Sociedade de Investigações Florestais 28(6): 889-894.

20. Logsdon, N.B., Finger, Z., Estevão, J.G., 2005: Descrição dendrológica e caracterização físico-mecânica da madeira de Amescla-Aroeira, Protium heptaphyllum (Aubl.) March. (Burseraceae) (Dendrological description and physical-mechanical characterization of Amescla-Aroeira, Protium heptaphyllum (Aubl.) March. (Burseraceae). Revista Madeira Arquitetura e Engenharia 6(17)

21. Lorenzi, H., 1998: Árvores Brasileiras: Manual de identificação de plantas arbóreas nativas do Brasil (Brazilian Trees: Identification Manual of Brazilian Trees). Plantarum, Nova Odessa - SP, Brazil, 352 pp.

22. Machado, J.S., Louzada, J.L., Santos, A.J.A., Nunes, L., Anjos, O., Rodrigues, J., Simões, R.M.S., Pereira, H., 2014: Variation of wood density and mechanical properties of blackwood (Acacia melanoxylon R. Br.). Materials and Design 56: 975-980.

23. Montgomery, D.C., 2012: Design and analysis of experiments. Wiley, New York, USA, $752 \mathrm{pp}$.

24. Morando, T.C., Christoforo, A.L., Aquino, V.B. de M., Lahr, F.A.R., Rezende, G.B.M., Ferreira, R.T.L., 2019: Characterization of the wood species Qualea albiflora for structural purposes. Wood Research 64(5): 769-776.

25. Nascimento, M.F., Almeida, D.H., Almeida, T.H., Christoforo, A., Lahr, F.A.R., 2018: Physical and mechanical properties of sabiá wood (Mimosa caesalpiniaefolia Bentham.). Current Journal of Applied Science and Technology 25(4): 1-5.

26. Nogueira, M.C. de J.A., Almeida, D.H., Araujo, V.A. de, Vasconcelos, J.S., Christoforo, A.L., Almeida, T.H., Lahr, F.A.R., 2019: Physical and mechanical properties of Eucalyptus saligna wood for timber structures. Ambiente Construído19(2): 233-239.

27. Pertuzzatti, A., Missio, A.L., de Cademartori, P.H.G., Santini, E.J., Haselein, C.R., Berger, C., Gatto, D.A., Tondi, G., 2018: Effect of process parameters in the thermomechanical densification of Pinus elliottii and Eucalyptus grandis fast-growing wood. BioResources 13(1): 1576-1590.

28. Ruelle, J., Beauchêne, J., Yamamoto, H., Thibaut, B., 2011: Variations in physical and mechanical properties between tension and opposite wood from three tropical rainforest species. Wood Science and Technology 45(2): 339-357.

29. Silva, C.E.G., De Almeida, D.H., De Almeida, T.H., Chahud, E., Branco, L.A.M.N., Campos, C.I., Lahr, F.A.R., Christoforo, A.L., 2018: Influence of the procurement site on physical and mechanical properties of Cupiúba wood species. BioResources 13(2): 4118-4131.

30. Silveira, L.H.C., Rezende, A.V., Vale, A.T. Do., 2013: Teor de umidade e densidade básica da madeira de nove espécies comerciais amazônicas (Moisture content and basic wood density of nine commercial Amazonian tree species). Acta Amazonica 43(2): 179-184.

31. ter Steege, H., Mota de Oliveira, S., Pitman, N.C.A., Sabatier, D., Antonelli, A., Guevara Andino, J.E., Aymard, G.A., Salomão, R.P., 2019: Towards a dynamic list of Amazonian tree species. Scientific Reports 9(1): 3501.

32. Steege, H. Ter, Vaessen, R.W., Cárdenas-López, D., Sabatier, D., Antonelli, A., Oliveira, S.M., Pitman, N.C.A., Jørgensen, P.M., Salomão, R.P., 2016: The discovery of the Amazonian tree flora with an updated checklist of all known tree taxa. Scientific Reports 6: article number 29549. 
Vinicius Borges De Moura Aquino*, Marcus Vinicius Pereira De Freitas,

Claudia Queiroz De Vasconcelos

Federal University Of Southern And Southeastern Pará

Technology Faculty

Santana Do Araguaia, Pará, Brazil

*Corresponding author: aquino.vini@hotmail.com

João Paulo Boff Almeida, Felipe Nascimento Arroyo,

Edson Fernando Castanheira Rodrigues, André Luis Christoforo

Federal University Of São Carlos

Department Of Civil Engineering

São Carlos, São Paulo, Brazil

Diego Henrique De Almeida

Federal University Of Rondonia

Department Of Civil Engineering

Porto Velho, Rondonia, Brazil

Sergio Augusto Mello Silva

São Paulo State University

Department Of Civil Engineering

Ilha Solteira, São Paulo, Brazil

Diogo Aparecido Lopes Silva

Federal University Of São Carlos

Department Of Production Engineering

Sorocaba, São Paulo, Brazil

Roberto Vasconcelos Pinheiro

Mato Grosso State University

Department Of Civil Engineering

Sinop, Mato Grosso, Brazil

Francisco Antonio Rocco Lahr

University Of São Paulo

Department Of Structural Engineering

São Carlos, São Paulo, Brazil 